Acta Universitatis Wratislaviensis No 3741

PRAWO CCCXXI Wrocław 2016

DOI: $10.19195 / 0524-4544.321 .5$

\author{
MARIAN J. PTAK \\ Uniwersytet Wrocławski \\ marian.ptak@prawo.uni.wroc.pl
}

\title{
Zjazd książąt śląskich z 1329 roku
}

W 1327 roku z inicjatywy Jana Luksemburskiego odbyły się trzy zjazdy książąt śląskich, których rezultatem była wasalizacja książąt górnośląskich oraz nabycie pełni praw książęcych przez króla czeskiego do Księstwa Wrocławskiego od Piastowicza Henryka VI, ze skutkiem po jego śmierci ${ }^{1}$. Jako rzeczywisty król Czech i tytularny Polski zapoczątkował w ten sposób politykę uzależniania od siebie książąt polskich na podstawie indywidualnych kontraktów lennych, ale uwzględniających ich grupowe interesy i zwyczajowe prawo książęce. Jej celem było pozbawienie Władysława Łokietka politycznych wpływów na Śląsku i w dalszej perspektywie tronu polskiego. Szczególną rolę w tej polityce miało odegrać Księstwo Wrocławskie, z Wrocławiem jako tradycyjnym ośrodkiem politycznym i ustrojowo-prawnym ${ }^{2}$. W dokumencie wystawionym stanom ziemi wrocławskiej w 1327 roku Luksemburczyk zobowiązał się bowiem do przyłączania do niej uzyskanych przez siebie ziem polskich. Mogło to prowadzić do powstania alternatywnego Królestwa Polskiego ze stolicą we Wrocławiu pod jego berłem³ .

W 1328 roku brakuje informacji o zjazdach książąt śląskich, także z udziałem króla czeskiego, którego absorbowały w tym czasie sprawy zachodnioeuropejskie. U schyłku tego roku jest potwierdzona jego obecność na Śląsku, gdzie

1 M.J. Ptak, Zjazdy ksiażą ślaskich z 1327 roku, „Prawo” CCCXIX, Wrocław 2015, s. 85-98.

2 Wymienionym w Kronice Galla na pierwszym miejscu wśród głównych stolic Królestwa Polskiego, przed Krakowem i Sandomierzem. Anonim tzw. Gall, Kronika polska, przeł. R. Grodecki, wstęp i oprac. M. Plezia, Wrocław 2008, s. 72; Anonima tzw. Galla kronika czyli dzieje ksiażat $i$ władców polskich, wydał, wstępem i komentarzem opatrzył K. Maleczyński, „Pomniki dziejowe Polski”, seria II - t. II, Kraków 1952, s. 75: ... in Wratislaw et in Cracou et in Sudomir sedes regni principales...

${ }^{3}$ Po śmierci Henryka VI, zgodnie z aktem z 1327 roku, król czeski stał się księciem wrocławskim. 
we Wrocławiu 20 grudnia wydał dokument dla mieszczanina kłodzkiego ${ }^{4}$. Był to pobyt związany z wyjazdem z Pragi w dniu 6 grudnia w kierunku Prus, w trakcie którego udało mu się załagodzić spór między biskupem Nankierem i wrocławską kapitułą katedralną oraz władzami miejskimi Wrocławia i być może powstrzymać akcje zbrojne Bolesława III przeciw Henrykowi VI ${ }^{5}$.

Początek 1329 roku był okresem sukcesów dyplomatycznych i militarnych Jana Luksemburskiego. W zwycięskiej wyprawie pruskiej wziął udział jeden z jego wasali śląskich, książę Bolko niemodliński (dux Slesie de Valkenbergh) ${ }^{6}$. Zawarł przymierze z Zakonem Krzyżackim skierowane przeciwko Łokietkowi i 12 marca w Toruniu, jako król Czech i Polski, darował Krzyżakom Pomorze ${ }^{7}$. Natomiast w dniu 29 marca władający Księstwem Płockim Wańko uznał się jego lennikiem $^{8}$. Płock będzie odtąd pojawiał się w dokumentach dotyczących książąt śląskich. U schyłku drugiej dekady kwietnia tego roku wraz z wojskiem znajdował się już na Śląsku. Jego pobyt tutaj i relacje z książętami ilustruje syntetycznie sekwencja regestów śląskich obejmująca okres od 20 kwietnia do 29 maja9 . To okres Świąt Wielkanocnych, jak w 1327 roku. Celem niniejszego opracowania jest przyjrzenie się treści dokumentów będących ich przedmiotem w sposób bardziej szczegółowy niż czyniono to w dotychczasowej literaturze przedmiotu ${ }^{10}$.

${ }^{4}$ Regsten zur schlesischen Geschichte. 1327-1333, wyd. C. Grünhagen, K. Wutke, Codex Diplomaticus Silesiae, t. 22, Breslau 1903, nr 4778 (cyt. RS); F. Volkmer, W. Hohaus, Geschichtsquellen der Grafschaft Glatz, t. I, Habelschwerdt 1883, s. 50.

5 J. Dąbrowski, Dzieje polityczne Ślaska w latach 1290-1402, [w:] Historia Ślaska od najdawniejszych czasów do roku 1400, t. I, red. S. Kutrzeba, Kraków 1933, s. 384-387.

${ }^{6}$ RS 4790.

7 Tekst w thumaczeniu na język polski [w:] Jana Długosza Roczniki czyli Kroniki Stawnego Królestwa Polskiego, Ksiega dziewiata 1300-1370, Warszawa 2009, s. 176-179. Śląsk w 1329 roku pozostał całkowicie poza polem obserwacji Długosza. Nie poświęcił mu też większej uwagi S.B. Klose, Von Breslau. Dokumentirte Geschichte und Beschreibung. In Briefen. Zweiter Band, Breslau 1781, s. 103.

${ }^{8}$ Akt hołdowniczy Wańka zob. H. Jireček (wyd.), Korunní Archiv Český, v Praze 1896, nr 81, natomiast rewersał Jana Codex diplomaticus et commemorationum Masoviae generalia, coll. J.C. Kochanowski, t. I, Varsoviae 1919, nr 59.

9 RS 4828-4846, 4851.

10 C. Grünhagen, Geschichte Schlesiens. Erster Band: Bis zum Eintritt der habsburgischen Herrschft 1527, Gotha 1884, s. 143-145; A. Bachmann, Geschichte Böhmens, Gotha 1899, s. 777; E. Schieche, Politische Geschichte von 1327-1526, [w:] Geschichte Schlesiens, Band I Von der Urzeit bis zum Jahre 1526, Breslau 1938, s. 159-160; J. Dąbrowski, op. cit., s. 394-400; Z. Wojciechowski, Ustrój polityczny Ślaska, [w:] Historia Ślaska od najdawniejszych czasów do roku 1400, t. I, red. S. Kutrzeba, Kraków 1933, s. 751-762; S. Śreniowski, Historia ustroju Ślaska, Katowice-Wrocław 1948, s. 32; K. Maleczyński, Historia Ślaska. Tom I Do roku 1763, Część I do połowy XIV w., Wrocław 1960, s. 555-557; P. Moraw, Das Mittelalter (bis 1469), [w:] Deutsche Geschichte im Osten Europas. Schlesien, wyd. N. Conrads, Berlin 1994, s. 89; R. Żerelik, Dzieje Ślqska do 1526 roku, [w:] M. Czapliński, et al., Historia Ślaska, Wrocław 2002, s. 71; K. Orzechowski, Historia ustroju Ślaska 1202-1740, Wrocław 2005, s. 60-66; W. Mrozowicz, Dolny Ślask w latach 13271526, [w:] Dolny Ślask. Monografia historyczna, red. W. Wrzesiński, Wrocław 2006, s. 106. 
W dniu 20 kwietnia Luksemburczyk wystawił dokument w języku łacińskim, w nieoznaczonym miejscu, dotyczący nadania braciom von Stercze (Heinrich, Gelfrid, Günther) podatków i innych świadczeń we wsiach Kostomłoty (Chozzenplocz, Kostenblut) i Nabłotno (Zabiloth, Sabloth), położonych w dystrykcie średzkim, wchodzącym wówczas w skład Księstwa Wrocławskiego ${ }^{11}$. Tym miejscem był najpewniej Wrocław, bowiem nieco wcześniej, mianowicie 14 kwietnia, książę wrocławski Henryk VI wydał tu dokument (też łaciński), którego odbiorcą był jego wierny rycerz Henryk Stercze wraz z braćmi (Dietrich zwany Coppo, Gelfrid i Günther ${ }^{12}$. Odnosił się on z kolei do wsi Krobielowice (Cribelwicz, Krieblowitz) w stołecznym dystrykcie wrocławskim ${ }^{13}$. Rozrodzony rycerski ród Sterczów (Sterz, Sterzce, Scherzem) pojawił się w źródłach śląskich w 1308 roku, najpierw w otoczeniu książąt świdnickich, a następnie wrocławskich i oleśnickich. Był zatem osiadły w dwóch najważniejszych dystryktach Księstwa Wrocławskiego i zapewne odgrywał w tej grupie społecznej znacząca rolę. Po 1329 roku występowali nadal na listach świadków dokumentów wydawanych przez Bolka świdnickiego oraz Bolesława legnickiego (dystrykt namysłowski) ${ }^{14}$. Przychylność takiego rodu rycerskiego, nawet dla króla czeskiego, zwłaszcza mającego przejąc $\mathrm{w}$ niedalekiej przyszłości pełnię władzy książęcej w Księstwie Wrocławskim i snującego plany polityczne w odniesieniu do innych niezwasalizowanych jeszcze ksiazżąt, nie była do pogardzenia ${ }^{15}$. Dokument ten wskazuje na coraz lepsze relacje króla z rycerstwem wrocławskim, z którym być może spotkał się w tym czasie. Jest on ponadto kolejnym przykładem powstałej już na kwietniowym zjeździe książąt we Wrocławiu w 1327 roku praktyki wystawiania dokumentów adresowanych do poddanych księstwa przez przyszłego księcia wrocławskiego za życia aktualnie jeszcze panującego w nim Henryka VI.

11 RS 4828. Archiwum Państwowe we Wrocławiu (cyt. APWr.), Repertorium Frobenianum $I, 124$. Kostomłoty już w XII wieku były ważnym miejscem targowym (forum Costomlot) przy drodze handlowej z Wrocławia do Strzegomia i ze Środy Śląskiej do Sobótki. W połowie XIII wieku organizowano w nim cotygodniowe targi i nazywane było miastem (civitas Costomblot). Zob. H. Weczerka (wyd.), Handbuch der historischen Stätten. Schlesien, Stuttgart 2003, s. 243-244.

12 RS 4826; APWr., Rep. 67, Klasztor św. Wincentego we Wrocławiu, nr 196.

13 Wieś o tej nazwie, położona około $20 \mathrm{~km}$ na południowy-zachód od Wrocławia, występuje w źródłach w 1321 roku jako majątek rycerski. W 1417 roku została nabyta przez klasztor św. Wincentego na Piasku i była jego własnością do sekularyzacji w 1810 roku. Państwo pruskie w 1814 roku podarowało ją wraz z innymi jedenastoma wsiami i folwarkami marszałkowi polnemu Gerhardowi Leberechtowi Blücherowi, księciu von Wahlstat (obecnie Legnickie Pole), za zasługi w wojnie wyzwoleńczej z Napoleonem Bonaparte. Nowy właściciel rozbudował istniejący tu renesansowy zamek z dużym rozmachem, który znajdował się w rękach jego spadkobierców do 1945 roku. Przetrwał w nienajgorszej kondycji do dnia dzisiejszego. Zob. H. Weczerka, op. cit., s. 253-254.

14 RS 4961, 5266, 5267, 5276, 5158.

15 Wspomniany Henryk został później mianowany przez Jana Luksemburskiego starostą Księstwa Wrocławskiego (1341-1343). Pochodził zapewne z niemieckiego rodu rycerskiego, choć nie można jednoznacznie wykluczyć jego polskiej proweniencji. Więcej na temat rodu Stercza zob. T. Jurek, Obce rycerstwo na Ślasku do połowy XIV wieku, Poznań 1998, s. 291-292. 
Następne dni przypadały na święta Wielkiej Nocy, zapewne wolne od większej aktywności politycznej, którą wznowiono dopiero we wtorek, w dniu 25 kwietnia. Zostały wówczas wydane we Wrocławiu trzy dokumenty przez księcia Bolesława III jako księcia legnickiego, który oznajmił w nich, że złożył swojemu panu, Janowi Luksemburskiemu, przyrzeczenie zachowania dotychczasowych praw i dokumentów je zabezpieczających (Handfeste) mieszczanom Legnicy, Chojnowa i Złotoryi oraz niezastawiania pobieranych od nich podatków ${ }^{16}$. Wskazują one na prowadzoną przez księcia politykę zaciągania długów i naruszania w związku z tym przywilejów miejskich. Można się domyślać, że wydano je z inicjatywy i na prośbę zaniepokojonych tą polityką władz miejskich, wzorujących się w swoich relacjach z księciem na Wrocławiu. Potwierdziły one pośrednio wyłączne prawo Bolesława do Księstwa Legnickiego, kwestionowane przez jego brata Władysława, zapewne w zamian za uznanie zwierzchnictwa lennego króla czeskiego, którego nazywa już wprost swoim panem. Król występuje w nich w roli obrońcy praw trzech najważniejszych miast Księstwa Legnickiego, jako senior lenny Bolesława oraz przyszły książę wrocławski. Jak się wydaje, były one rezultatem rozmów prowadzonych przez króla z udziałem wszystkich trzech książąt wrocławskiej linii Piastów. Władysław przestał być ostatecznie „rządzącym księciem”, a Bolesław został lennikiem króla Jana, co potwierdził wydany przez króla dwa tygodnie później kolejny dokument.

Drugą pilną sprawą było uregulowanie relacji króla z czterema książętami linii głogowskiej (w kolejności starszeństwa: Henryk IV żagański, Konrad oleśnicki, Jan ścinawski i Przemko), którą zapewne omawiano w następnych dniach tego tygodnia. Dopiero w sobotę 29 kwietnia książę (dux) Śląska i pan Ścinawy Jan — jako pierwszy z tej linii — wystawił we Wrocławiu, po naradzie i za zgodą swoich wiernych i przyjaciół oraz miast i ziem, czyli politycznych stanów Księstwa Ścinawskiego, dokument w języku łacińskim uwierzytelniony własną pieczęcią z charakterystyczną legenda, w której tytułował się dziedzicem Królestwa Polskiego (heres Regni Poloniae $)^{17}$. Tytułu tego nie użył jednak w intytulacji tego dokumentu, choć używał go wcześniej w innych ${ }^{18}$. Oznajmił w nim, że swobodnie i z własnej woli

16 Urkundenbuch der Stadt Liegnitz und ihres Weichbildes bis zum Jahre 1455, wyd. F.W. Schirrmacher Liegnitz 1866, s. 59; APWr., Rep. 132a, Depozyt miasta Chojnowa, nr 7, Depozyt miasta Złotoryi, nr 16.

17 Lehns=und Besitzurkunden Schlesiens und seiner einzelnen Fürstenthümer im Mittelalter, wyd. C. Grünhagen, H. Markgraf, cz. I, Leipzig 1881 (cyt. GM I), s. 129. Oryginał w Archiwum Nadwornym w Wiedniu. W RS 4833 pomija się legendę pieczęci księcia (JOHS DI GRA HERES REGNI POLONIE DUX SLIE DNS STINAVIE). Przedruk także u G. Thebesiusa, Liegnitzische Jahrbücher, Jauer 1733, s. 169.

18 Jako przykład może służyć dokument księcia Jana ścinawskiego, wystawiony w Górze Śląskiej w dniu 25 listopada 1328 roku i nadający jej prawo miejskie Głogowa, w którym tytułował się dziedzicem Królestwa Polskiego, księciem Śląska i Głogowa oraz panem ze Ścinawy. RS 4774. APWr., Dokumenty miasta Góry Śląskiej, nr 9. Góra, wraz z otaczającym ją dystryktem, graniczyła bezpośrednio z Wielkopolską, a więc stanowiła najbardziej wysuniętą na północny-wschód rubież 
zrezygnował z ziem, miast i zamków: Ścinawa, Lubin i Góra, wraz ze wszystkimi swoimi prawami, wolnościami i panowaniem (dominium) nabytymi od przodków, na rzecz Jana Luksemburskiego, które jednak otrzymał na powrót w prawnej formie wieczystego lenna (feudum perpetuum). Nazywa tu Luksemburczyka „naszym prawdziwym panem". Jako przyczynę tej dyspozycji podał poczynione przez siebie w Księstwie Wrocławskim szkody oraz przyrzeczenie króla, że nie będzie z tego powodu przeciw niemu występował w żaden sposób. Miał tu na myśli własne działania zbrojne, podejmowane w 1328 roku wespół z Bolesławem III ${ }^{19}$. Dokument nadania lenna wystawiony przez króla czeskiego uważa się za zaginiony.

Tymczasem król czeski zjednywał sobie wybrane jednostki organizacyjne Kościoła, mające swoje siedziby w Księstwie Wrocławskim. W dniu 1 maja nadał bowiem klasztorowi klarysek we Wrocławiu przywilej zwalniający go od świadczeń na rzecz książąt i panów (principes et domini) z tytułu posiadania przezeń młynów na Odrze oraz nadający mu prawo do budowy nowych ${ }^{20}$. Stanowił zatem kontynuację koncesji poczynionych już w 1327 roku. Jego fundatorką była żona księcia wrocławskiego Henryka II Pobożnego, Anna, córka króla czeskiego Przemysła Ottokara $\mathrm{I}^{21}$. Fundację zatwierdził w 1256 roku papież Aleksander IV, a w następnym roku pierwsze klaryski sprowadzono z Pragi. Kościół klasztorny pod wezwaniem św. Damiana i Klary konsekrowano w 1260 roku, do którego dobudowano kaplicę św. Jadwigi, która zaczęła pełnić rolę mauzoleum Piastów wrocławskich ${ }^{22}$. Klasztor miał charakter elitarny. Wśród pierwszych dziesięciu opatek aż osiem było Piastównami. Miejsce spoczynku znalazła tu księżna Anna (zm. 1265), syn Henryka Pobożnego Henryk III Biały (zm. 1266) oraz jego córka Jadwiga (druga opatka, zm. 1318), syn Bolesława Rogatki - Henryk V Brzuchaty (zm. 1296) oraz jego żona Elżbieta (córka księcia wielkopolskiego Bolesława Pobożnego, zm. 1304) i wszystkie trzy jego córki: Anna (zm. 1343), Jadwiga (zm. 1347) i Elżbieta (zm. 1356). Pochowany w kaplicy św. Jadwigi klasztoru klarysek we Wrocławiu został również ostatni książę wrocławski Henryk VI (zm. 1335) oraz jego córki — Elżbieta (zm. 1328) i najmłodsza Małgorzata (opatka, zm. 1379).

Dwa dni później (3 maja) Bolesław legnicki wydał dokument potwierdzający sprzedaż między dwoma rycerzami wsi Minkowskie (Mikoffsky, Minkowsky, Seydlitzruh) w dystrykcie namysłowskim, należącym wówczas do Księstwa Brzeskie-

Śląska. W dokumencie z 25 lipca 1334 roku nadal na pieczęci tytułował się heres Polonie, dux Slesie, dominus Stinavie. RS 5360.

19 J. Dąbrowski, op. cit., s. 384.

20 RS 4835; APWr., Rep. 63, Klasztor Klarysek św. Klary we Wrocławiu, nr 73.

${ }^{21}$ K. Jasiński, Rodowód Piastów ślaskich, t. I, Piastowie wrocławscy i legnicko-brzescy, Wrocław 1973, s. 95-97 n. Klasztor klarysek zsekularyzowano w 1810 roku i jego zabudowania przekazano zakonowi urszulanek.

22 T.M. Pietsch, Zur Geschichte des Breslauer Klarenstiftes des jetzigen Ursulinenklosters, [w:] Zur schlesischen Kirchengeschichte, t. 27, 1937; H. Kulig, Die Standesverhältnisse des Breslauer Klarenstiftes im Mittelalter, Breslau 1939; T. Kozaczewski, Kościół klarysek, dwór księżnej Anny a dom kupców, „Zeszyty Naukowe Politechniki Wrocławskiej”, 36, 1960, Architektura, z. 4, s. 83-90. 
go $^{23}$. Dowodzi on dalszego pobytu księcia we Wrocławiu oraz jego aktywności nie tylko w sprawach relacji z królem, ale także z poddanymi księstwa, które przypadło mu bezpośrednio na podstawie podziału Księstwa Wrocławskiego w 1311 roku.

W tym samym dniu zostały wydane tutaj kolejne dwa dokumenty, tym razem dotyczące najstarszego księcia z linii świdnickiej, Henryka jaworskiego. Henryk, tytułujący się też księciem Śląska i panem Książa (Fürstenberg), oznajmiał w pierwszym z nich, że sprzedał Luksemburczykowi ziemię zgorzelecką, z wyłączeniem Lubania, miasta i ziemi Leśna, zamku Czocha i Świecie, czyli południowo-wschodni zakątek Górnych Łużyc, ponadto miasto Żary oraz zamki Trzebiel i Przewóz położone w ziemi łużyckiej (Dolne Łużyce) ${ }^{24}$. W zamian otrzymał w dożywotnie posiadanie położone w Czechach, Trutnov (Trautenau) i Królewski Dwór nad Łabą (Dvưr Králové, Königinhof) ${ }^{25}$, które po jego śmierci miały ponownie wrócić do Królestwa Czech. Łużyckie posiadłości przypadły Henrykowi jaworskiemu w 1319 roku po śmierci ostatniego margrabiego brandenburskiego z dynastii Askańczyków, Waldemara, na mocy układu zawartego 22 września tego roku z Janem Luksemburskim, również pretendującym do sukcesji po nim ${ }^{26}$. Tytułem prawnym Henryka był fakt, że jego matką była córka margrabiego brandenburskiego Ottona V Długiego, Beatrycze ${ }^{27}$. Wśród świadków wrocławskiego dokumentu, którzy uwierzytelnili go własnymi pieczęciami, wymieniono biskupa Miśni Witko oraz książąt i panów: Rudolfa saskiego, Henryka wrocławskiego, Bolesława legnickiego, Bolka niemodlińskiego, Bolka opolskiego, braci Henryka i Konrada głogowskiego. Drugi dokument tej samej treści, ale bez formuły świadków, skierował Henryk jaworski do cesarza niemieckiego Ludwika z prośbą o potwierdzenie $^{28}$. Taka konfirmacja była konieczna ze względu na zwierzchnictwo lennego

23 RS 4836; Namysłowska księga ziemska z końca XV wieku, APWr., Rep. 16, Księstwo Wrocławskie, sygn. III, 16b, fol. 93.

${ }^{24}$ RS 4837; J.Ch. Lünig, Des Teutschen Reichs-Archiv Partis spec. Continuatio I, Fortsetzung, Leipzig 1711, s. 1284; G. Köhler, Codex Diplomaticus Lustatiae Superioris, t. I, Görlitz 1856, s. 285. Lubań wraz z tzw. okręgiem Kwisy (Quiskreis) znajdowały się w jego władaniu aż do 1346 roku. W tym roku terytorium to przypadło Czechom i powstał związek sześciu górnołużyckich miast (Budziszyn, Zgorzelec, Kamieniec, Lubań, Lubij i Żytawa), który odgrywał dużą rolę w życiu politycznym Górnych Łużyc. J. Šołta, Zarys dziejów Serbotużyczan, Wrocław-Warszawa 1984; Dzieje Górnych Łużyc. Władza, spoleczeństwo i kultura od średniowiecza do końca XX wieku, red. J. Bahlcke, Warszawa 2007.

${ }^{25}$ Lenno trutnowskie, powstałe w 1277 roku, obejmowało także Królewski Dwór nad Łaba. Było położone w północnych Czechach przy granicy ze Śląskiem i Księstwem Świdnickim. W 1365 roku Karol IV przekazał je książętom opolskim, Władysławowi i Bolkowi, którzy mieli je przejąć po śmierci Bolka świdnickiego (zm. 1368) i jego małżonki Agnieszki (zm. 1392). W końcu XIV wieku lenno trutnowskie przypadło królowi Wacławowi IV i stało się dożywociem małżonek królewskich.

26 RS 3953-3955.

27 K. Jasiński, op. cit., t. I, s. 148-151.

28 RS 4838; J.P. Ludewig, Reliquiae manuscriptorum omnis aevi diplomatum ac monumentorum ineditorum, t. V, Frankfurt 1725, s. 558; J.Ch. Lünig, Codex Germaniae Diplomaticus, worinnen viele... Documenta enthalten, cz. I, Frankfurt 1733, s. 983; G. Köhler, op. cit., s. 275. 
cesarza nad Łużycami. Z dokumentów tych wynika, że 3 maja 1329 roku odbyło się we Wrocławiu zgromadzenie siedmiu książąt śląskich, w tym dwóch górnośląskich, z udziałem króla czeskiego i towarzyszących mu dostojników oraz biskupa miśnieńskiego i księcia saskiego. Jak się wydaje, zostało ono zapoczątkowane już 20 kwietnia. Mogli w nim uczestniczyć także książęta niewymienieni w powyższej formule świadków. Zwraca bowiem uwagę brak w niej Jana ścinawskiego, którego obecność we Wrocławiu jest potwierdzona 25 i 29 kwietnia. Zwołani na zjazd w 1329 roku w większości byli jeszcze formalnie wolnymi książętami, poza dwoma górnośląskimi. Zastanawia brak na tej liście wszystkich zwasalizowanych już w 1327 roku książąt górnośląskich. Być może ze względu na główny cel zjazdu ich obecność zdaniem króla, ale także książąt panujących w księstwach dalej położonych, nie była konieczna, poza najbliżej osiadłymi, a więc w przypadku górnośląskich - Bolkiem niemodlińskim i Bolkiem opolskim ${ }^{29}$. Omawiana transakcja była poprzedzona przez akcję władz miejskich Zgorzelca, które za pośrednictwem Karola, syna Luksemburczyka, wystąiły z prośbą o przyłączenie do Korony Czeskiej $^{30}$. Przedstawiały one panowanie Henryka jako uciążliwe jarzmo (grave iugum). Rozsiewano też pogłoski, że dybie on na życie króla. Miało to zapewne wpłynąć na osłabienie pozycji Henryka, który jednak nie uznał lennego zwierzchnictwa Luksemburczyka ${ }^{31}$.

W kolejnych dniach 4-6 maja (czwartek-sobota) toczyły się zapewne dalsze deliberacje dotyczące książąt linii głogowskiej i wrocławskiej, o czym świadczy sekwencja sześciu dokumentów z 7-10 maja. Rozpoczyna ją łacińskojęzyczny dokument z 7 maja wystawiony we Wrocławiu przez króla czeskiego, który oświadczał, że Konrad oleśnicki przyjął od niego swoje aktualne ziemie w lenno (in feudum recipiet) jako wieczysty książę i wasal (princeps et vasallus) króla, jego dziedziców i sukcesorów oraz Królestwa Czech. Przekazał w nim następnie rozstrzygnięcie sprawy swoich świadczeń wobec Konrada, tytułującego się księciem Śląska i panem w Oleśnicy (dux Zlecie et domino in Olsna), dwóm innym książętom, księciu Śląska i panu Żagania Henrykowi (przekazanie księstwa seniorowi nastąpiło dopiero 9 maja), który był bratem Konrada oleśnickiego, oraz księciu Niemodlina Bolkowi ${ }^{32}$. Zatem rozstrzygnięcie tej kwestii powierzył król samym książętom, a ściślej przedstawicielowi linii głogowskiej i opolskiej. Dokument przyznał im stanowisko sędziów polubownych (legitimos et amicabiles compositores), mających wydać w tej sprawie wyrok w ciagu czternastu dni, licząc od nie-

29 Można w tym upatrywać początków tzw. zjazdów najbliżej osiadłych. Punktem odniesienia był w nich stołeczny Wrocław i Księstwo Wrocławskie.

30 J. Dąbrowski, op. cit., s. 395.

31 Nie jest więc prawdziwe twierdzenie autorów najnowszej monografii dziejów Górnych Łużyc (J. Bahlcke, op. cit., s. 109), że Henryk jaworski w 1329 roku musiał uznać wraz z innymi książętami śląskimi Jana Luksemburskiego za swojego suwerena.

32 RS 4839; GM II, s. 16. Konrad oleśnicki i Bolko niemodliński byli zięciami Henryka wrocławskiego. Bolko poślubił jego córkę Ofkę, natomiast Konrad Elżbietę. 
dzieli Misericordia domini, czyli drugiej niedzieli po Wielkiej Nocy, przypadającej w 1329 roku właśnie 7 maja. Wynika stąd, że wyrok miał zapaść do dnia 21 maja (niedziela Cantate). Wskazuje to na towarzyszące zawarciu kontraktu lennego obu stron pertraktacje dotyczące praw króla w tej relacji, które w oczywisty sposób określały również pozycję ustrojowo-prawną księcia. Na podkreślenie zasługuje powierzenie rozstrzygnięcia tej kwestii samym książętom, z których tylko jeden tytułował się śląskim i był w tej grupie najstarszym, a drugi tylko niemodlińskim i najstarszym wśród nieśląskich (opolskich), obecnych na tym zjeździe.

Kolejny dokument, z następnego dnia (8 maja), wystawił Bolesław legnicki ${ }^{33}$. Potwierdził w nim umowę sprzedaży wsi w dystrykcie oławskim zawartą między braćmi szlacheckiej kondycji, a więc konfirmował transakcję ziemią w Księstwie Brzeskim, a nie Legnickim. Jest on dowodem jego dalszej aktywności we Wrocławiu w odniesieniu do szlachty tego księstwa.

Z 9 maja pochodzą aż trzy ważne dokumenty, dotyczące sytuacji prawnej książąt z linii wrocławskiej: Bolesława legnickiego, Henryka VI wrocławskiego i Władysława oraz z linii głogowskiej: Konrada oleśnickiego, Henryka żagańskiego, Jana ścinawskiego i Przemka głogowskiego.

Pierwszy dokument pozostawał w ścisłym związku z trzema dokumentami Bolesława legnickiego z 25 kwietnia $^{34}$. Wystawiony przez Luksemburczyka i uwierzytelniony jego pieczęcią został sporządzony w języku niemieckim (!). Nie zawiera on listy świadków, ale na wstępie król czeski oznajmił, że sporządzono go za radą jego manów (mit unserer manne rat) i z udziałem Bolesława, w celu zaniechania dalszych działań wojennych (umb alle brache und krig) między królem i księciem, z powodu jego konfliktów z braćmi, Henrykiem i Władysławem (Vlotko), książętami z Śląska i panami z Wrocławia. Dotyczyły one ziemi legnickiej wraz z zamkiem i miastem Legnica, Chojnowa z zamkiem i miastem, miasta Złotoryi oraz zamku w Chocianowie ze wszystkimi przynależnościami, czyli Księstwa Legnickiego ${ }^{35}$. Jak już wspomniano, z roszczeniami do tego księstwa, być może zachęcony przez brata Henryka albo nawet samego króla, wystąpił przed zwołaniem zjazdu książę Władysław. Król zakomunikował, że w trybie polubownego pojednania (gesünet und geeynet) wszystkie swoje ziemie (zastawione i niezastawione) Bolesław przekazał jemu oraz przyszłym królom Czech i czeskiej Rzeszy (riches ze Beheim), bez przymusu i z własnej woli. Zostały one następnie nadane Bolesławowi i jego następcom jako prawe lenno dziedziczne (zu einem rechten erblehen). Dokument określił najpierw ogólnie ich położenie przez stwierdzenie, że znajdują się po obu stronach Odry. Po czym wymieniono zamki i miasta, które wyznaczały zasięg przestrzenny tych ziem. Na pierwszym miejscu znalazły się zamki i miasta wymienione już wcześniej, tworzące ówcze-

33 RS 4840; APWr., Rep. 21, Księstwo Brzeskie, sygn. 381.

34 GM I, s. 302-304.

35 RS 4843; GM I, s. 302. 
sne Księstwo Legnickie, które znajdowały się na lewym, południowo-zachodnim brzegu Odry. Na drugim miejscu wymieniono inne ziemie (alle andere eygen lant) i określające je zamki i miasta w następującej kolejności: Brzeg — zamek i miasto, Niemcza - zamek i miasto, Oława - miasto, Grodków - miasto, Namysłów — zamek i miasto, Bierutów — zamek i miasto, Kluczbork — zamek i miasto, Gorzów Śląski, Jamna ${ }^{36}$ i Byczyna wraz z weichbildami oraz wszystkimi przynależnościami (ziemie, majątki i ludzie, zarówno „ulennieni”, jak i „nieulennieni”). Były to zatem ziemie, weichbildy, zamki i miasta ówczesnego Księstwa Brzeskiego. W dokumencie podkreślono, że ziemie te zostały nadane w lenno Bolesławowi ze wszystkimi prawami, wolnościami i pożytkami, od dawna istniejącymi i odziedziczonymi przez niego po swoich przodkach. Król równocześnie zobowiązał się wobec niego i jego dziedziców, że wszystkie te prawa i wolności zostaną w pełni zachowane, bez względu na sposób, w jaki zostały uzyskane przez księcia i jego przodków, oraz nie będą im stawiane żadne przeszkody. Także, gdy będą dotyczyły świadczeń lennych (manschaft), pieniędzy, czynszów, ceł, wyższych i niższych sądów, zamków, miast, wsi i ziem. Przede wszystkim kopalń złota, srebra, ołowiu, cyny oraz innych kruszców, a ponadto mennic, księży, klasztorów, mniszych dworów, lenn kościelnych, Żydów albo zwierzyny łownej. Następnie zostały przedstawione konkretne uprawnienia książęce. Na pierwszym miejscu wymieniono swobodne prawo księcia do burzenia starych i budowy nowych twierdz. Kolejne przepisy dotyczyły sądownictwa. Król zobowiązał się do niemieszania się w sprawy sądowe, w których książęcy ludzie na miarę rycerską (rittermessig leut) występowali przeciw księciu albo odwrotnie. W przypadku odmowy wymiaru prawa (sprawiedliwości) manom przez ich księcia albo niemożności dochodzenia przez nich swoich praw przed manami księcia (sąd manów), książę zobowiązany był do dania im prawa przed królem, który mógł powierzyć tę funkcję towarzyszom (genozzen) księcia. Pod tym pojęciem należy rozumieć sąd składający się z innych książąt, najpewniej śląskich. W przypadku posiadania przez mana majątku nadanego przez króla i innego przez księcia, z tytułu pierwszego majątku odpowiadał przed królem, natomiast z drugiego przed księciem i jego manami, ale nigdzie indziej. Jeśli człowiek nie będący towarzyszem księcia albo jego manem (cudzoziemiec) wystapił z roszczeniem przeciw księciu i jego następcom, dotyczącym długu, majątku lub innej sprawy, należało ją rozstrzygnąć

36 Tyefense. W wykazach nazw miejscowości niemiecko-polskich i polsko-niemieckich identyfikuje się ją z nazwą Tiefensee - Głębocko albo Jamna k. Grodkowa, M. Kaemmerer, Ortsnamenverzeichnis der Ortschaften jenseits von Oder und Neiße, Leer 1988. Usytuowanie tej miejscowości między Gorzowem Śląskim i Byczyną sugeruje jednak jej lokalizację po prawej stronie Odry. W dokumencie Henryka V wrocławskiego z 6 maja 1294 roku, potwierdzającym zawarcie przez niego układu z Henrykiem głogowskim, wymieniono trzy twierdze (vesten): Brig stat und huz, ...huz Tifense, ... Rochliz deme huze ... . GM II, s. 3-8. Jest to zatem Jamna, położona $8 \mathrm{~km}$ na południe od Grodkowa nad rzeką Nysą. Znajdował się tu książęcy zamek wodny, którego zarządcą w 1272 roku był comes Deczko de Tyfense. Zob. H. Weczerka, op. cit., s. 536. 
przed manami księcia. W takiej sytuacji król zobowiązał się do nieprzyjmowania takich spraw. Jeśli nie mogli dochodzić swojego prawa przed manami księcia, wówczas mogli się odwołać do króla we wszystkich sprawach, z powodu których byli wezwani przed króla. Król zobowiązany był wyznaczyć sędziów spośród towarzyszy księcia, jeśli nie mógł sam wysłuchać stron, które musiały się stawić w takim sądzie tylko wówczas, gdy odbywał się w ziemi wrocławskiej (in dem lande ze Brezlab). Jeśli towarzysz księcia (czyli inny książę), jeden albo kilku, wystąpi ze skargą przeciw księciu lub jego następcom, może wówczas wystapić z taką skargą przed królem i ma się przed nim stawić tylko wtedy, gdy będzie przebywał w Czechach albo w Polsce. Ludzi księcia: rycerskich, na miarę rycerską i kupców nie można było niepokoić i pojmać z powodu długów pieniężnych, zaciagnniętych przez księcia w ziemiach, miastach, wsiach i twierdzach króla czeskiego. Dopuszczalne jednak było występowanie z roszczeniem prawnym w sądzie przeciwko poręczycielom, jeśli znaleźli się w ziemiach królewskich. Książę $\mathrm{i}$ jego następcy byli zobligowani do przyjmowania lenna (lehenn ze enpfahen) od króla czeskiego i jego następców, ale tylko na obszarze Królestwa Czech. W przypadku konieczności sprzedaży albo zastawienia jakiegoś miasta, albo twierdzy będącej ośrodkiem weichbildu (geweichbildete veste), książę zobowiązany był do zaoferowania jej najpierw królowi. Jeśli król nie był zainteresowany tą oferta, to nabywcą mógł zostać towarzysz księcia lub jakiś stosowny man, który musiał jednak przyjąć takie miasto lub twierdzę w lenno od króla czeskiego, w taki sam sposób jak ma czynić książę i jego następcy. Król zastrzegł jednak sobie prawo, także w imieniu swoich następców, do wykupu zastawionego miasta albo twierdzy, za kwotę ustanowionego zastawu, jeśli nie został on w terminie zniesiony. Jeśli książę i jego sukcesorzy będą w stanie ów zastaw wykupić ze wszystkimi prawami, król zobowiązywał się do ponownego przekazania go księciu. Sprzedaż lub zastaw majątku manom księcia, na który składały się miasta i twierdze $\mathrm{z}$ weichbildami (ale nie miasta $\mathrm{z}$ weichbildem!), nie wymagała złożenia wcześniejszej oferty królowi. Nie byli oni też zobowiązani do przyjęcia takiego lenna od króla, lecz tylko od księcia. Zwracają uwagę występujące tu dystynkcje majątkowe, wymagające pogłębionych studiów, zwłaszcza ze względu na ich późniejszą częstotliwość i reperkusje prawno-ustrojowe. Wydanie tego dokumentu poprzedzały zapewne trudne rozmowy. Wiadomo, że Bolesław, będący szwagrem Luksemburczyka, czynił mu gorzkie wymówki z powodu umowy zawartej z jego młodszym bratem Henrykiem VI w 1327 roku, pozbawiającej go praw sukcesyjnych do Księstwa Wrocławskiego. Powoływał się przy tym na złożoną mu wcześniej przez króla obietnicę, że będzie respektował jego prawa i oczekiwania oraz chronił go przed każdym, kto będzie w nie godził. W odpowiedzi usłyszał, że nie miał na myśli siebie, bo przecież nie może występować przeciw sobie samemu ${ }^{37}$. Król wystapił w tym dokumencie w roli arbitra i równocześnie przyszłego księcia

37 C. Grünhagen, Geschichte..., s. 143-144. 
wrocławskiego. W zamian za uznanie zwierzchnictwa lennego króla Bolesław uzyskał formalne potwierdzenie swoich praw do Księstwa Legnickiego, związane z ostatecznym pozbawieniem tych praw brata Władysława. Zwierzchnictwo lenne króla objęło wszystkie posiadłości Bolesława, a więc nie tylko Księstwo Legnickie, ale także Brzeskie. Książę wrocławski Henryk VI był formalnie nadal wolnym księciem, a jego księstwo terytorium alodialnym, a nie lennym. Pozbawiony jednak został na mocy tego dokumentu prawa do ewentualnego dziedziczenia Księstwa Legnickiego i Brzeskiego. Jego korzystne stanowisko wobec starszego brata wynikało $z$ faktu nabycia prawa własności do księstwa w trybie umownym przez króla czeskiego, choć z naruszeniem zwyczajowego prawa książąt polskich.

Drugi dokument, dotyczący linii głogowskiej, został wydany przez Jana Luksemburskiego, bez listy świadków, ale z uwierzytelniającą pieczęcią króla, w związku z uznaniem się za jego lennika (furst und man) Konrada oleśnickiego ${ }^{38}$. Sporządzono go nie w języku łacińskim, lecz niemieckim. Podkreślono na wstępie, że Konrad uznał się lennikiem króla czeskiego ze szczególnej miłości i pożądania, ze wszystkich ziem, które odziedziczył po swoich przodkach i bracie Bolesławie $(\text { Polke })^{39}$. Podniesiono również, że uczynił to bez przymusu, po uprzednim rozważnym wsparciu i pilnej radzie swoich przyjaciół i manów oraz ich dobrej woli. Pod tym sformułowaniem krył się współudział, w tym doniosłym akcie prawnym i politycznym, pierwszoplanowego czynnika społecznego ówczesnego Księstwa Oleśnickiego, czyli szlachty, której stanowisko zostało najpewniej wyrażone na sejmiku ziemskim odbytym we Wrocławiu albo w położonej niedaleko Oleśnicy. Podkreślono też wyraźnie, że ziemie, majątki i ludzi książę przekazał królowi zgodnie z treścią dokumentów, które wcześniej mu przedstawił. Ich treści nie znamy. Dokument lenny wymieniał jednak prawa i obowiązki księcia wynikające z tych dokumentów. Na wstępie stwierdzał, że książę i jego spadkobiercy, tytułujący się książętami z Śląska i z Głogowa oraz panami Oleśnicy (hrczogen von Slezen und von Glogow und herren ze Olsen), zostali wieczystymi lennikami (fursten und mannen) króla i Królestwa Czech. Całe Księstwo Oleśnickie zostało nadane jako prawe lenno dziedziczne (zu einem rechten erblehn) i w związku z tym król uroczyście przyrzekł księciu, w imieniu własnym i swoich sukcesorów, zachować wszystkie jego prawa i chronić je całą swoją potęgą przed wszelką przemocą i nieprawościami. Na księciu ciążył z kolei obowiązek świadczenia pomocy

38 RS 4841; GM II, s. 17-19. Ze starego kopiarza oleśnickiego pochodzącego z końca XIV wieku; Transumpt wrocławskiej kapituły katedralnej z 1336 roku, APWr., Rep. 132c, Depozyt Archiwum Księstwa Oleśnickiego, nr 77.

39 Bolesław był synem Henryka III głogowskiego (zm. 1309). Urodził się na przełomie 1293 i 1294 roku. W 1312 roku przypadło mu wraz z bratem Konradem terytorium z ośrodkami w Oleśnicy, Kaliszu i Gnieźnie, a po zajęciu Wielkopolski w 1314 roku przez Władysława Łokietka tylko terytoria śląskie, z ośrodkami w Namysłowie i Oleśnicy. Konrad władał dzielnicą namysłowską, a Bolesław oleśnicką. Po śmierci brata, najprawdopodobniej już w 1320 roku, Konrad przeją jego dzielnicę i zaczął się tytułować księciem oleśnickim. K. Jasiński, op. cit., t. II, s. 96-98. 
całą swoją mocą królowi, ale tylko w ziemiach Czech i Polski (!). W przypadku wezwania do tej powinności poza granicami tych ziem król zobowiązał się to czynić w taki sposób, aby jej wykonanie nie było zbyt uciążliwe. Król zobowiązał się również do odpowiadania w imieniu księcia wobec czeskiej Rzeszy, jeśli zostanie zapytany w sprawie świadczeń lennych (manschft $)^{40}$. Ziemie odziedziczone przez Konrada po ojcu, w przypadku ich odzyskania przez króla przemocą lub w inny sposób, miały mu być ponownie nadane w lenno albo w zamian nadany inny majątek lub wypłacone pieniądze. Decyzje w tych sprawach miało podejmować czteroosobowe kolegium rozjemcze (rada czterech manów), do którego każda strona wybierała po dwóch sędziów. W celu uzyskania nadania lenna przez króla książę i jego dziedzice mieli o nie zabiegać tylko w granicach Królestwa Czech. Książę miał pełną władzę w swoich ziemiach budowania domów i twierdz oraz ich burzenia. Ponadto, jeśli uzna to za konieczne albo potrzebne, także pełną swobodę zastawienia albo sprzedaży ziemi, majątku lub zamku, które nie są ani ośrodkami weichbildu, ani państwa (herschaft ${ }^{41}$, komu zechcą. Weichbildy i państwa mógł zastawiać i sprzedawać swoim towarzyszom (genozzen) albo właściwym manom. Pod warunkiem jednak, że jako pierwszemu złoży ofertę zastawu lub sprzedaży królowi, który miał również prawo zniesienia każdego zastawu przez zapłatę kwoty zastawnej albo ceny sprzedaży. Jeśli król nie chciał lub nie mógł skorzystać z tej oferty, wówczas towarzysz, który kupił albo wziął w zastaw majątek mający weichbild, zobowiązany był do wzięcia tego majątku (zamek, twierdza, miasto) od króla w lenno, w taki sam sposób jak poprzednio. Określone też zostały zasady dziedziczenia. Uprawnionymi do dziedziczenia księstwa byli zstępni Konrada w linii męskiej, w pierwszej kolejności jego synowie, a w przypadku ich braku jego dwaj bracia, Henryk głogowski i Jan ścinawski oraz ich synowie. Pominięty został w tym dokumencie czwarty brat, Przemko głogowski, który do końca życia sprzeciwiał się uznaniu zwierzchnictwa lennego Jana Luksemburskiego. Jeśli był to warunek króla, to trzeba równocześnie zwrócić uwagę, że wyrazili nań zgodę jego trzej bracia. O jednoznacznie wrogiej wobec Luksemburczyka postawie Przemka świadczy jego wypowiedź odnotowana w Kronice Książąt Polskich, że „prędzej opuści swoją ziemię na jednym koniu niż podda się władzy jakiegokolwiek księcia"42. Swojej postawy nie zmienił aż do nagłej śmierci w dniu

${ }^{40}$ Nie jest to pomyłka, jak sugerują niemieccy wydawcy Regestów Śląskich. Powtarza się to bowiem także w dokumencie dotyczącym Bolesława legnickiego.

${ }^{41}$ Łacińskim odpowiednikiem tego terminu jest dominium. Rozumiano pod nim większe kompleksy majątkowe, które nie pełniły roli dystryktu lub weichbildu w strukturze terytorialnej księstwa.

42 Chronica principium Poloniae, [w:] Scriptores Rerum Silesiacarum oder Sammlung schlesischer Geschichtschreiber, wyd. G.A. Stenzel, t. I, Breslau 1835, s. 149: Primislaus, dux Glogoviensis, adhuc juvenis, sicut audivi a senioribus, bene rexit suam porcionem et quamvis impugnaretur per regem Bohemie super ejus subjeccione, nunquam tamen voluit consentire, sed dixit: pociup se velle terram exire, solus in equo, quam subjectus esse alicujus principis potestati. 
11 stycznia 1331 roku, którą przypisywano jego wasalom i podanej mu przez nich truciźnie. Początkowo wspólnie z bratem Henrykiem, a później samodzielnie do tragicznego końca, używał tytułu najpierw dziedzica Królestwa Polskiego i Poznania, a następnie tylko dziedzica Królestwa Polskiego ${ }^{43}$. Praktykę tę stosował z upodobaniem także Konrad oleśnicki, który jeszcze w 1358 roku używał na swojej pieczęci tytułu dziedzica Królestwa Polskiego ${ }^{44}$. W powyższym dokumencie znalazły się też przepisy dotyczące zabezpieczenia majątkowego córek księcia i jego następców. Prawem księcia było wyposażenie ich za życia przez ustanowienie zastawu na ziemiach, miastach, zamkach lub twierdzach. Nosiło ono nazwę skarbu narzeczeńskiego (prutschacz), czyli posagu. W przypadku wygaśnięcia linii męskiej księcia Konrada albo jego dwóch wymienionych braci królowi czeskiemu przysługiwało prawo zniesienia takiego zastawu przez zapłacenie kwoty zastawnej. Śmierć księcia przy równoczesnym braku ich wyposażenia za jego życia nakładała na króla czeskiego i jego sukcesorów obowiązek wydania ich za mąż i wyposażenia każdej córki w wysokości 2 tys. kop praskich groszy. Na szczególną uwagę zasługują przepisy dotyczące wymiaru sprawiedliwości. Żądania albo skargi poddanych (undergenozze odir Ir man) wobec księcia, dotyczące długów albo innych spraw, nie miały być przyjmowane przez króla, lecz rozstrzygane przez sądy właściwe w tych sprawach w księstwie. Wyjątek stanowiła tylko sytuacja, w której strona nie mogła zrealizować swojego prawa w sądzie księstwa, co kwalifikowano jako odmowę wymiaru sprawiedliwości (denagata iustitia) i umożliwiało rozsądzenie takiej sprawy przez króla. Jeśli król nie mógł takiej sprawy rozstrzygnąć osobiście z powodu swojej nieobecności, mógł zlecić to zadanie jednemu z książąt. Dokument nie precyzuje, czy takim zleceniobiorca mógł być tylko książę śląski. Stwierdza jednak, że miejscem takiego sądu mogła być tylko ziemia wrocławska (in dem lande ze Brezlaw), czyli zapewne Księstwo Wrocławskie, a w nim miasto Wrocław. W przypadku pozwania jednego księcia przez drugiego $\mathrm{w}$ jakiejś sprawie przed sąd króla, byli oni zobowiązani do stawienia się przed nim tylko w ziemiach Czech albo Polski. Dokument zakazywał niepokojenia i fantowania księcia Konrada i jego sukcesorów w sprawach długów i pieniędzy, w twierdzach i na obszarach królewskich, natomiast zezwalał na występowanie z roszczeniami wobec jego poręczycieli w sądzie, jeśli spotka ich się w ziemiach, na obszarach i w twierdzach królewskich.

Trzeci dokument też dotyczył linii głogowskiej. Został on napisany po łacinie, bez listy świadków, i uwierzytelniony tylko pieszą pieczęcią księcia, niezawierającą w legendzie aspiracji do tronu polskiego. Jego wystawcą był Henryk tytułujący się księciem z Śląska i Głogowa oraz panem z Żagania. Jest on w zasadzie, co do formy i treści, powtórzeniem dokumentu poprzedniego. Zawiera standardową formułę, że przyjął w lenno od króla Czech i Polski wszystkie swoje ziemie z podkre-

\footnotetext{
43 1319-1330. RS 3885, 4521, 4976.

44 1317-1358. RS 3656; GM II, s. 36-37.
} 
śleniem, że po obu stronach Odry, wraz ze wszystkimi swoimi dotychczasowymi wolnościami i prawami ${ }^{45}$. Wyliczono w nim jednak miasta i zamki określające terytorialny zasięg lennego władztwa Henryka żagańskiego: Żagań, Kożuchów, Szprotawa, Zielona Góra, Krosno, Nowogród Bobrzański, Otyń, Małomice, Puszków, Bobrowice, Sulechów, Świebodzin, Lubrza, Bytnica, Zbąszyń, Kopanica, Przyprostnia, Nietkowice, Babimost, Przemęt, Przewóz i Trzebiechów. Podkreślono w nim również, że Henryk dobrowolnie złożył hołd wierności (fidelitatis homagium) i osobistą przysiegę (iuramentum corporalis) królowi. Wymienione też zostały jego prawa i obowiązki, identyczne jak w przypadku Konrada. Książę zachował pełne prawo budowy nowych oraz naprawy i burzenia starych twierdz w swoich ziemiach. Wśród ewentualnych męskich sukcesorów Henryka wymieniono też Jana ścinawskiego, ale obok niego — Konrada oleśnickiego i pominięto, jak w poprzednim dokumencie, Przemka głogowskiego. W przypadku wymarcia linii męskiej księstwo miało przypaść dziedzicznie Królestwu Czech. W kwestii wymiaru sprawiedliwości powtórzono zasadę, że w sprawy sporne i sądowe między księciem i jego sukcesorami a poddanymi król nie mógł w żaden sposób się mieszać, jednak wyraźnie wymieniono w tym dokumencie kategorie poddanych: duchowni, mieszczanie, wieśniacy i żydzi. Szlachcie i wiernym księcia przyznano też prawo złożenia skargi wprost do króla w przypadku odmowy wymiaru sprawiedliwości. W takiej sytuacji książę osobiście albo za pośrednictwem swojego deputowanego musiał odpowiedzieć na królewski pozew i stawić się w miejscu, w którym król aktualnie przebywał, ale tylko na terytorium Czech i Polski (!). W przypadku zastępstwa króla przez innego prawdziwego księcia (coram altero vero principe) książę żagański miał się stawić tylko w sądzie odbywanym w ziemi wrocławskiej (terra Wratislaviensi). Pod pojęciem prawdziwego księcia krył się zapewne tylko miejscowy książę, czyli śląski. Kolejny przepis dotyczył sprzedaży bądź zastawu przez księcia jakiegoś terytorium i państwa (dominium). Przedmiotem ostatniego były służebności lenne księcia, które miały być świadczone tylko na obszarze Czech i Polski, natomiast poza nim tylko za wynagrodzeniem ze strony króla.

Ostatni dokument związany z nieprzerwanym pobytem we Wrocławiu króla czeskiego i książąt śląskich został spisany również po łacinie i wystawiony w dniu 10 maja przez Konrada, tytułującego się księciem Śląska i Głogowa oraz panem w Oleśnicy (dux Slesie et Glogovie et dominus in Olsna) i uwierzytelniony jego pieczęcią z dodatkowym tytułem, dziedzica Królestwa Polskiego ${ }^{46}$. Podkreślono w nim na wstępie, że nastąpiło to za radą przyjaciół i wiernych księcia i miało służyć dobru ziemi. Konrad oznajmił w nim, że przekazał wszystkie swoje ziemie, posiadane aktualnie i nabyte w przyszłości pod jakimkolwiek tytułem, wraz ze wszystkimi wolnościami i prawami, które uzyskał od swoich poprzed-

45 RS 4842; GM I, s. 129.

46 RS 4844; GM II, s. 19-21. W RS pominięto legendę tej pieczęci: S . CONRADI . DEI GRA HEREDIS . REGNI POLONIE . DUCIS. S / LIE . ET DNI . OL / ESNICENSIS. 
ników, Janowi Luksemburskiemu jako jego książę i wasal (princeps et vasallus suus). Dokument określa je dokładniej przez wymienienie miast i zamków po obu stronach Odry (fluvium, qui Odora dicitur), w następującej kolejności: Syców, Oleśnica, Milicz, Trzebnica, Żmigród, Wołów, Lubiąż, Wińsko, Wąsosz (wszystkie z miastami i zamkami) oraz Płock (Ploczk), Prusice i Sądowel. Zaskakuje na tej liście zwłaszcza obecność Płocka. Niemieccy wydawcy regestów śląskich sugerowali występowanie pod tą nazwą miejscowości Płoski (Pluskau) w powiecie wołowskim, co wydaje się mocno wątpliwe. Warto w tym kontekście zwrócić uwagę na następne dwie miejscowości. Okazuje się bowiem, że Prusice nie znajdowały się w tym czasie w posiadaniu Konrada, ponieważ wcześniej sprzedał je z prawem do wykupu Henrykowi VI. Z kolei Sądowel, będący dawniej ośrodkiem odrębnej kasztelanii, utracił dotychczasową funkcję ośrodka administracyjnego (okręg grodowy) na rzecz lokowanych na prawie niemieckim u schyłku XIII wieku miast, Góra Śląska i Wąsosz. Natomiast Góra należała w tym czasie do Jana ścinawskiego. Jak wyżej wspomniano, przed przyjazdem do Wrocławia książę płocki Wańko stał się wasalem Jana Luksemburskiego, a nazwa tej miejscowości pojawia się jeszcze w kolejnych dokumentach, także dotyczących zrzeczenia się przez Kazimierza Wielkiego praw do większości księstw śląskich z 1335 i 1339 roku $^{47}$. Dokument z 1335 roku wymienia wśród książąt śląskich, między Władysławem kozielskim i bytomskim oraz Leszkiem raciborskim, właśnie Wańka, czyli Wacława (Wenczezlaus princeps Masoviae dominus in Plotzk). Identycznie postapiono w dokumencie z 1339 roku. W dokumencie inkorporacyjnym Karola IV z 7 kwietnia 1348 roku wśród książąt i księstw śląskich wymieniono principatus Mazovie et ducatus in Ploczk ${ }^{48}$. W 1353 i 1356 roku Ludwik Węgierski i Kazimierz Wielki zrzekli się praw do Byczyny i Kluczborka w zamian za otrzymane wspólnie od Karola IV Księstwo Płockie (ducatus Plocczensis) ${ }^{49}$. Warto też zwrócić uwagę na dokument Henryka głogowskiego z 1351 roku, w którym jest mowa o otrzymaniu przez niego Księstwa Płockiego w lenno od króla czeskiego i o złożeniu $\mathrm{w}$ związku z tym stosownej przysięgi ${ }^{50}$. Wskazuje to na realną możliwość przekazania na zjeździe wrocławskim przynajmniej części swoich zwierzchnich praw wobec księcia płockiego i jego lennego terytorium Konradowi oleśnickiemu. Problem owych polityczno-prawnych relacji między Śląskiem i Mazowszem zasługuje niewątpliwie na wnikliwsze zbadanie. Powtórzono w nim następnie postanowienia dokumentu $\mathrm{z}$ dnia poprzedniego, w zasadzie bez większych zmian.

Po 10 maja zarówno król, jak i książęta Śląska nie wystawili żadnego dokumentu we Wrocławiu. W dniu 19 maja Jan Luksemburski przebywał w górnołużyckim

47 GM I, s. 4-6.

48 GM I, s. 10.

49 GM I, s. 331-332.

50 J.E. Böhme, Diplomatische Beyträge zur Untersuchung der Schlesischen Rechte und Geschichte, t. II, cz. I, Berlin 1775, s. 62-84, nr 91. Wykaz dokumentów przechowywanych w archiwum ziemskim Królestwa Czeskiego na zamku w Karlstein. 
Zgorzelcu, zapewne w celu odebrania hołdu od mieszczan zgorzeleckich i innych stanów z części Łużyc, którą 3 maja nabył od Henryka jaworskiego. Wystawił tu kolejne dwa dokumenty dotyczące książąt śląskich. W pierwszym z nich przyrzekł Bolesławowi legnickiemu, że nie będzie się mieszał w jego spory z poddanymi, za wyjątkiem tych, które będą dotyczyć szlachty (feudales et nobiles) ${ }^{51}$. A więc w relacjach z tą pierwszoplanową grupą społeczną król zagwarantował sobie jednak prawo ingerencji. W drugim przyrzekł Konradowi oleśnickiemu, za to, że został jego lennikiem, udzielić pomocy w sprawie miasta Prusic z przynależnymi doń wsiami, które książę przekazał Henrykowi wrocławskiemu, pod warunkiem możliwego odkupienia, a jeśli byłoby to niemożliwe zabezpieczenia odszkodowania ${ }^{52}$. Do ustalenia jego wysokości wyznaczył jako sędziów Henryka żagańskiego i Bolka niemodlińskiego. Prusice od 1322 roku znajdowały się w zastawnym posiadaniu Henryka VI i dopiero w 1340 roku pełne zwierzchnictwo uzyskał nad nimi Konrad ${ }^{53}$. Zatem swojej obietnicy, jak wielu innych, Luksemburczyk nie dotrzymał.

Po pobycie w Zgorzelcu król powrócił do Wrocławia, co potwierdza tylko jeden, ale bardzo ważny i często pomijany dokument, wydany tutaj przez niego 29 maja $^{54}$. Jest on pozbawiony listy świadków i nie jest uwierzytelniony żadną pieczęcią, a jego niemiecki (!) tekst jest znany tylko z transumptu króla Wacława z 1367 roku, zawartego w widymacie króla Jerzego z Podiebradu z 1459 roku, oraz z transumptu z 1422 roku. Ten z 1422 roku był być może związany z faktem objęcia tronu czeskiego po Wacławie IV przez jego brata Zygmunta (1419-1437). Jan Luksemburski oznajmił w nim, że książę Konrad z Śląska i Głogowa oraz pan Oleśnicy przedłożył mu dokumenty cesarskie stwierdzające, że jego przodkowie i on sam są wolnymi książętami i prawymi dziedzicami Korony Polskiej. Swoją ziemię ze wszystkimi przynależnościami otrzymał od swoich przodków i brata Bolka (Bolcke). Podlega ona obecnie królowi, który go przyjął jako księcia i len-

51 RS 4845; Transumpt z 1615 roku opublikowano w GM I, s. 305.

52 RS 4846; Stary kopiarz oleśnicki, GM II, s. 21.

53 W. Haeusler, Geschichte des Fürstenthums Oels bis zum Aussterben der Piastischen Herzogslinie, Breslau 1883, s. 346; GM II, s. 28.

54 RS 4851; Transumpt króla Wacława z 13 października 1367 roku, znajdujący się w vidimusie króla Jerzego sporządzonym w Świdnicy 6 września 1459 roku opublikował J.J. Füldener, Bio- et Bibliographia Silesiaca, Das ist: Schlesische Bibliotek und Bücher=Historie, ..., Repositor I. Volumen I, Breslau 1731, s. 467-475; Drugi transumpt z 5 czerwca 1422 roku (z mniej zmodernizowana ortografią niż u Füldenera, ale z błędami) znajdował się w APWr., Depozyt dokumentów Księstwa Oleśnickiego, nr 171. Wydawcy RS zwracają jednak uwagę na potrzebę zbadania tego dokumentu i porównania go z dokumentem z 9 maja 1329 r. [RS 4841]. W GM II, s. 38 tylko streszczenie z informacją, że znajdował się w starym kopiarzu z XIV wieku, znajdującym się w Książęcym Archiwum w Oleśnicy (p. 6). Podano jednak inną datację: 23 lutego 1367 roku (an s. Mathias abent des h. zwelfbothen unsers konigreiches in dem vierden jare.). To czwarty rok panowania Wacława IV, który był synem Karola IV i koregentem od 1363 roku. Dokument Jerzego z Podiebradu, wydany w drugim roku panowania w dniu 6 września 1459 roku w Świdnicy, potwierdzający braciom, Konradowi i Konradowi Białemu, otrzymane przez przodków przywileje też tylko w formie regestu (GM I, s. 60). 
nika oraz nadał mu ją jako prawe lenno dziedziczne. W przypadku domagania się przez króla od księcia służby lennej miał on zabezpieczyć jego cześć i wystapić w imieniu księcia, gdy Rzymska Rzesza będzie się od niego domagała złożenia hołdu. Król zobowiązał się w nim, że jeśli odzyska zamki lub majątki należące do księcia, wówczas przekaże je księciu albo da coś w zamian. Tę sprawę miało rozstrzygać czteroosobowe kolegium składające się z dwóch sędziów wyznaczonych przez króla i dwóch przez księcia. W celu objęcia lenna książęta musieli się udać do króla, ale tylko wówczas, gdy przebywał w ziemi czeskiej. Książętom przyznano prawo budowania i burzenia w swoich ziemiach zamków. Ponadto budowania kopalń i wydobywania w nich złota, srebra i wszystkich innych kruszców oraz rozporządzania nimi wedle swojego uznania. Mieli też prawo bicia monet ze zwyczajowymi domieszkami, zgodnie z królewską walutą ziemską, czemu nie mogą przeciwstawić się królewskie ziemie i miasta. Nałożono na nich obowiązek zapewnienia pokoju i ochrony przed rabusiami i złoczyńcami na drogach prowadzących przez ziemie księstwa. Uznane zostało ich prawo do ustanawiania ceł $\mathrm{i}$ ich poboru, przeciw czemu nie mogli występować ludzie króla. Dokument pozwalał im też przyjmować w swoich ziemiach Żydów i obdarzać ich pokojem (regale żydowskie). Szczególnie dużo uwagi poświęcono w nim sądownictwu. Jeśli król zamierzał wystąić przeciw księciu Konradowi lub jego następcom z prawnym roszczeniem, wówczas zobowiązany był do mianowania jednego spośród książąt śląskich jako sędziego. Sprawa miała być rozstrzygnięta przed tym sędzią i innymi wezwanymi w tym celu książętami. Miejscem tego rozstrzygnięcia miał być dwór we Wrocławiu. W ten sam sposób miały być rozstrzygnięte sprawy, w których skarżącym był książę. Książę powinien najpierw upominać króla i następnie w identycznej formie wzywać przed sąd. Wyrok takiego sądu król miał wykonać w terminie trzech miesięcy. W przeciwnym razie książę mógł zatrzymać ludzi króla i zajmować ich majątek, a król był zobowiązany do zapłaty odszkodowania. W przypadku wystapienia z roszczeniem wobec księcia oleśnickiego przez innego księcia, na królu ciążył obowiązek (w opisany wyżej sposób) natychmiastowego wyznaczenia sądu składającego się z książąt śląskich. Zarówno książę, jak i jego następcy, nie byli zobowiązani do odpowiadania na inne skargi. Mieli ponadto prawo domagania się od króla ochrony w takiej sytuacji. Skarga wasala księcia przeciw księciu miała być złożona na ręce manów i sędziów, którzy w tych sprawach byli właściwi, i na ich rozstrzygnięciu należało poprzestać. Jednak jeśli za pośrednictwem dokumentu (mit orkunde) zostanie udowodnione, że wasalowi odmówiono prawa, wówczas sprawa trafiała do króla, który rozstrzygał ją w swoim sądzie. Omawiany dokument sprawia wrażenie potwierdzonego przez króla wyroku sądu polubownego dwóch książąt śląskich, powołanego do życia w dniu 7 maja, który miał wydać swój wyrok w dniu 21 maja. W tym dniu król być może przebywał jeszcze w Zgorzelcu.

W 1329 roku znajdowało się na Śląsku 18 książąt (wraz z ostatecznie odsuniętym od rządów Władysławem legnickim). Wśród nich większość stanowili 
książęta śląscy w ścisłym znaczeniu, czyli dolnośląscy (11), pozostali to opolscy, czyli górnośląscy (7). Z opolskich we Wrocławiu potwierdzona źródłowo jest tylko obecność dwóch (Bolka opolskiego i Bolka niemodlińskiego), natomiast ze śląskich aż siedmiu. W grupie książąt głogowskich zabrakło najmłodszego Przemka głogowskiego, natomiast świdnickich: Bolka II świdnickiego, Henryka II świdnickiego i Bolka ziębickiego. Spośród książąt linii świdnickiej tylko Henryk I jaworski (najstarszy w tej linii, którego wiek mieścił się w przedziale 33-37 lat) wziął udział w zjeździe wrocławskim, ale nie uznał zwierzchnictwa lennego króla czeskiego.

Seniorem wśród książąt linii wrocławskiej był bez wattpienia Bolesław III brzeski i legnicki (38 lat), natomiast w linii głogowskiej Henryk IV żagański (3640 lat) albo Konrad I namysłowski i oleśnicki (33-36 lata). Wśród nieobecnych górnośląskich najstarszymi byli Władysław kozielski i bytomski (36-42 lat), Kazimierz cieszyński (39 lat) i Leszek raciborski (37-39 lat), natomiast wśród obecnych na wrocławskim zjeździe Bolko niemodliński (34-39 lat).

Spośród górnośląskich zabrakło: Władysława kozielskiego i bytomskiego, Alberta strzeleckiego, Leszka raciborskiego, Jana oświęcimskiego i Kazimierza cieszyńskiego. Za wyjątkiem Alberta strzeleckiego uznali oni zwierzchnictwo lenne Jana Luksemburskiego już w 1327 roku. Wedle klasycznych zasad prawa lennego powinni oni towarzyszyć swojemu seniorowi, przynajmniej na terytorium Śląska oraz innych ziem polskich.

Za księcia śląskiego uchodził też biskup wrocławski. Już Henryk I z Wierzbna (1302-1319) tytułował się księciem ${ }^{55}$. Nie można w związku z tym wykluczyć udziału w tym zjeździe biskupa Nankera (1326-1341), obecnego w tym czasie w mieście. W dniu 29 kwietnia uczestniczył w posiedzeniu kapituły katedralnej, na której wystawił dokument potwierdzający rozstrzygnięcie sporu wewnątrzkościelnego ${ }^{56}$. Inne zachowane dokumenty nie potwierdzaja jednak tego przypuszczenia. Jest to zrozumiałe, ponieważ do Wrocławia trafił z Krakowa z polecenia Władysława Łokietka i reprezentował tu jego interesy. W tym okresie biskup wrocławski Nanker występował energicznie przeciw naruszającym majątki, prawa i przychody Kościoła wrocławskiego oraz papiestwa (świętopietrze w formie pogłównego). Być może próbował zainteresować tym problemem obradujących we Wrocławiu książąt śląskich i króla ale, jak się wydaje, bezskutecznie. Składane skargi na zaistniałą sytuację trafiały do papieża, rezydującego w Avignonie. W dniu 1 czerwca papież Jan XXII w odpowiedzi na nie zwrócił się do Jana Luksemburskiego z ponagleniem o wzięcie w obronę kościoła wrocławskiego

55 J. Pater, Poczet biskupów wrocławskich, Wrocław 2000, s. 47.

56 RS 4834. Archiwum Archidiecezjalne we Wrocławiu, sygn. A 19. Przedruk ze statutu ze schyłku XV wieku opublikował J. Heyne, Dokumentirte Geschichte des Bisthums und Hochstiftes Breslau, t. I, Breslau 1860, s. 685. 
przed działaniami księcia ziębickiego Bolka i innych przeciwników ${ }^{57}$. Listy takiej samej treści skierował też do króla Węgier, Polski (Władysława Łokietka), arcybiskupa gnieźnieńskiego, biskupa ołomunieckiego oraz indywidualnie do książąt śląskich: Bolesława legnickiego, Henryka (Heynko) jaworskiego, braci Bolesława niemodlińskiego i Bolka opolskiego, Leszka (Lestko) raciborskiego, Władysława kozielskiego i bytomskiego, oraz braci: Henryka żagańskiego, Konrada oleśnickiego, Przemka głogowskiego i Jana ścinawskiego.

Kolejny pobyt Jana Luksemburskiego we Wrocławiu jest odnotowany w dniu 29 lipca 1329 roku, w którym wydał tylko jeden dokument, dający mieszczanom Zgorzelca przywilej dotyczący przenoszenia własności dóbr lennych ${ }^{58}$. Jest on kolejnym wyrazem ożywionych politycznych relacji między Śląskiem i Górnymi Łużycami oraz ich stołecznymi miastami.

Jak każde tego rodzaju zgromadzenie, wymagało ono znacznych nakładów finansowych, obciążających zwłaszcza udzielających gościny. Byli nimi przede wszystkim obywatele miasta Wrocławia. Jego wydatki ad honorem regis, ducum et aliorum dominorum $\mathrm{w}$ roku 1329 (ponad trzy tygodnie) wyniosły 416 marek czyli grzywien srebra, a więc znacznie więcej niż na poprzednim zjeździe (ponad tydzień) w 1327 roku (280 grzywien $)^{59}$.

$$
* * *
$$

Dokumentacja pobytu Jana Luksemburskiego we Wrocławiu w dniach 20 kwietnia-10 maja i 29 maja 1329 roku dowodzi, że nie odbyło się tu jakieś amorficzne spotkanie króla czeskiego, roszczącego sobie prawa do tronu polskiego, z poszczególnymi książętami śląskimi, ale zjazd wezwanych przez niego książąt, którzy nie byli jego wasalami, lecz z różnych powodów takiej opcji nie wykluczali. Spośród zwasalizowanych już książąt górnośląskich wezwał tylko dwóch, władających terytoriami sąsiadującymi bezpośrednio z Księstwem Brzeskim i Nyskim biskupa wrocławskiego (najbliżej osiadli). Uczestnikiem zjazdu był też książę wrocławski Henryk VI, który wasalem nie był, oraz przyszły książę wrocławski w osobie króla czeskiego. Partykularne zjazdy książąt śląskich nie były zjawiskiem nowym i jego początku możemy upatrywać już w latach sześćdziesiątych i siedemdziesiątych XII wieku, jako rezultatu dzielenia dzielnicy śląskiej i stopniowego powiększania się liczby książąt na podstawie zasad sukcesyjnych polskiego prawa ksiazżęcego. Celem zjazdu, po skutecznym zwasalizowaniu książąt Górnego Śląska i uzyskaniu sukcesji w Księstwie Wrocławskim w 1327

57 RS 4852. Przedruk ze źródeł watykańskich [w:] Zeitschrift des Vereins für Geschichte und Altertum Schlesiens, t. I, Breslau 1859, s. 198 n.

58 RS 4865; Vidimus z 1509 roku opublikował z fałszywą datą G. Köhler, op. cit., s. 284.

59 Henricus Pauper. Rechnungen der Stadt Breslau von 1299-1358, nebst zwei Rationarien von 1386 und 1387, dem Liber Imperatoris vom Jahre 1377 und den ältesten Breslauer Statuten, wyd. C. Grünhagen, Breslau 1860. 
roku, było przede wszystkim sformalizowanie polityczno-prawnych relacji książąt Dolnego Śląska z królem czeskim przez zawieranie indywidualnych kontraktów lennych. Nie wiadomo, czy wezwania skierowano do wszystkich, czy tylko do tych książąt, którzy w swoich kalkulacjach politycznych takiej możliwości nie wykluczali. Wiadomo natomiast, że zjazd zakończył się polubownym rozwiązaniem sporu książąt wrocławskich, dotyczącego podziału Księstwa Wrocławskiego na trzy części przed osiemnastu laty. Henryk VI, na mocy układu z Janem Luksemburskim z 1327 roku, zachował dożywotnio władzę książęcą w Księstwie Wrocławskim, ale swoim jedynym sukcesorem uczynił króla czeskiego. Odrzucono roszczenia jego brata Władysława do Księstwa Legnickiego i potwierdzono wszystkie prawa trzeciego brata, Bolesława, do sprawowania w nim władzy. Bolesław uznał zwierzchnictwo lenne Jana Luksemburskiego i jego sukcesorów w odniesieniu do dwóch księstw, przypadłego mu w podziale z 1311 roku Księstwa Brzeskiego oraz Księstwa Legnickiego, które pierwotnie miało przypaść Władysławowi. Rozstrzygnięte zostały również relacje króla z książętami linii głogowskiej, ale też w sposób niejednolity. Trzej z nich: Henryk, Konrad i Jan uznali zwierzchnictwo Luksemburczyka. Pierwszy w odniesieniu do Księstwa Żagańskiego, drugi do Księstwa Oleśnickiego, a trzeci do Księstwa Ścinawskiego. Czwarty z braci, Przemko, władający Księstwem Głogowskim, był zdecydowanym przeciwnikiem uznawania nad sobą zwierzchnictwa jakiegokolwiek innego księcia i był wierny temu poglądowi do swojej śmierci w 1331 roku. Podobną postawę prezentowali książęta linii świdnickiej, spośród których tylko książę Henryk jaworski zjawił się we Wrocławiu. Zawarł tu, poświadczoną przez obecnych w tym dniu książąt, umowę z Janem Luksemburskim, w której zrzekł się na jego rzecz części Górnych Łużyc, w zamian za prawo dożywotniego posiadania dwóch kompleksów majątkowych w Czechach. Być może była to forma nacisku, skłaniającego go do uznania zwierzchnictwa lennego, która jednak okazała się nieskuteczna. Książęta linii świdnickiej z zadziwiającą konsekwencją przez wiele lat będą bronić się przed tą perspektywą.

Mało wiadomo o organizacji tego zjazdu. Zapewne jego termin określił król w drodze powrotnej z wyprawy pruskiej. Posłańcy królewscy, zaopatrzeni w odpowiednie pełnomocnictwa, wzywali książąt do osobistego stawienia się we Wrocławiu w okresie poprzedzającym święta wielkanocne. Nie wiadomo, gdzie W mieście odbyło się pierwsze plenarne posiedzenie zgromadzonych (ratusz, nowy zamek?), na którym najpewniej król czeski (i przyszły książę wrocławski) przedstawił cel spotkania $\mathrm{w}$ formie propozycji. W odpowiedzi na propozycję książęta przystapili do obrad, czyli deliberacji. Jak się wydaje, miały one charakter mieszany, czyli odbywały się sesje wspólne wszystkich książąt oraz grupowe, w których brali udział tylko książęta określonych linii, osobno wrocławskiej i głogowskiej. Do załatwiania konkretnych spraw powoływano też wydziały, czyli komisje zjazdu. Taki dwuosobowy wydział, pełniący funkcję sądu polubownego, powołano do dokładniejszego sformułowania praw króla względem Konrada 
oleśnickiego, natomiast czteroosobowy do rozstrzygania sporów majątkowych między tym księciem i królem. W trakcie zjazdu niektórzy książęta załatwiali też sprawy jednostkowe swoich poddanych i wydawali stosowne dokumenty. Sprawy będące przedmiotem obrad zjazdu były też załatwiane poza Wrocławiem, w łużyckim Zgorzelcu, gdzie król wystawiał stosowne dokumenty, korygujące albo uzupełniające dokumenty lenne. Wskazuje to na kontraktowy i deliberacyjny sposób nawiązywania stosunków lennych między książętami śląskimi i królem czeskim. Kontrakt lenny nie jawi się tutaj jako ściśle sformalizowana umowa o charakterze adhezyjnym. Stąd też przy wielu podobieństwach są również widoczne różnice w treści dokumentów lennych książąt śląskich. Ale lektura ich tekstów przekonuje, że wasalni książęta zachowali w zasadzie swoje dotychczasowe prawa, wolności i panowanie nad podległymi im terytoriami i poddaną im ludnością. Ich ograniczanie wynikało głównie $\mathrm{z}$ faktu zaakceptowania przez nich szczególnych praw króla czeskiego jako seniora lennego. Dotychczasowe polskie prawo książęce funkcjonowało odtąd w koegzystencji z czeskim prawem królewskim i niemieckim prawem lennym. Dokumenty lenne formalizowały wzajemne relacje książąt i króla czeskiego oraz książąt między sobą, zwłaszcza w sferze jurysdykcji. Utrwaliły tym samym wspólne w całym Śląsku instytucje ustroju politycznego, które przetrwały do połowy XVIII wieku. Należy je w związku z tym uważać za pierwsze akty prawne o charakterze fundamentalnym i konstytucyjnym nie tylko poszczególnych księstw śląskich, ale także późniejszego Księstwa Górnego i Dolnego Śląska.

\section{Bibliografia}

\section{Wykaz źródeł}

Anonim tzw. Gall., Kronika polska, przeł. R. Grodecki, wstęp i oprac. M. Plezia, Wrocław 1996.

Anonima tzw. Galla kronika czyli dzieje książat $i$ władców polskich, wydał, wstępem i komentarzem opatrzył K. Maleczyński, „Pomniki dziejowe Polski”, seria II — t. II, Kraków 1952.

Archiwum Państwowe we Wrocławiu: Rep. 16, Księstwo Wrocławskie; Rep. 21, Księstwo Brzeskie; Rep. 33, Księstwo Oleśnickie, sprawy domu panującego (1329-1839), kopiarz (1285-1380); Rep. 63, Klasztor Klarysek Św. Klary we Wrocławiu; Rep. 132a, Depozyt miasta Chojnowa; Rep. 132a, Depozyt miasta Złotoryi; Rep. 132c, Depozyty archiwów książęcych i stanowych; I. Depozyt archiwum Księstwa Oleśnickiego.

Böhme J.E., Diplomatische Beyträge zur Utersuchung der Schlesischen Rechte und Geschichte, t. II, cz. I, Berlin 1775.

Chronica principium Poloniae, [w:] Scriptores Rerum Silesiacarum oder Sammlung schlesischer Geschichtschreiber, wyd. G.A. Stenzel, t. I, Breslau 1835.

Codex diplomaticus et commemorationum Masoviae generalis, wyd. J.K. Kochanowski, Warszawa 1919.

Das Formelbuch des Domherrn Arnold von Protzan, Codex Diplomaticus Silesiae, t. V, red. W. Wattenbach, Breslau 1862. 
Füldener J.J., Bio- et Bibliographia Silesiaca, Das ist: Schlesische Bibliothek und Bücher=Historie,... Repositor I. Volumen I, Breslau 1731.

Grünhagen C., Wutke K., Regesten zur schlesischen Geschichte. 1327-1333, [w:] Codex Diplomaticus Silesiae, t. 22, Breslau 1903.

Henricus Pauper. Rechnungen der Stadt Breslau von 1299-1358, nebst zwei Rationarien von 1385 und 1387, dem Liber Imperatoris vom Jahre 1377 und den ältesten Breslauer Statuten, wyd. C. Grühagen, [w:] Codex Diplomaticus Silesiae, t. 3, Breslau 1860.

Heyne J., Dokumentirte Geschichte des Bisthums und Hochstiftes Breslau, t. I, Breslau 1860.

Jana Dlugosza Roczniki czyli Kroniki sławnego Królestwa Polskiego, Księa dziewiata 1300-1370, Warszawa 2009.

Köhler G., Codex Diplomaticus Lusatiae Superioris, t. 1, Görlitz 1856.

Korunní Archiv Český, wyd. Jireček H., v Praze 1896.

Lehns=und Besitzurkunden Schlesiens und seiner einzelnen Fürstenthümer im Mittelalter, wyd. C. Grünhagen, H. Markgraf, cz. I, Leipzig 1881, cz. II, Leipzig 1883.

Ludewig J.P., Reliquiae manuscriptorum omnis aevi diplomatum ac monumentorum ineditorum, t. V, Frankfurt 1725.

Lünig J.Ch., Des Teutschen Reichs-Archiv Partis spec. Continuatio I, Fortsetzung, Leipzig 1711.

Lünig J.Ch., Codex Germaniae Diplomaticus, worinnen viele ... Documenta enthalten, cz. I, Frankfurt 1733.

Schirrmacher F.W., Urkundenbuch der Stadt Liegnitz und ihres Weichbildes bis zum Jahre 1455, Liegniz 1866.

Thebesius G., Liegnitzische Jahrbücher, (red. G.B. Scharffen), t. II, Jauer 1733.

Volkmer F., Hohaus W., Geschichtsquellen der Grafschaft Glatz, Habelschwerdt 1883, t. I.

\section{Literatura}

Bachmann A., Geschichte Böhmens. Erster Band (Bis 1400), Gotha 1899.

Boras Z., Ksiażęta piastowscy Ślaska, Katowice 1974.

Dąbrowski J., Dzieje polityczne Ślaska w latach 1290-1402, [w:] Historia Ślaska od najdawniejszych czasów do roku 1400, red. S. Kutrzeba, t. I, Kraków 1933.

Grünhagen C., Geschichte Schlesiens, Erster Band: Bis zum Weintritt der habsburgischen Herrschaft 1527, Gotha 1884.

Haeusler W., Geschichte des Fürstenthums Oels bis zum Aussterben der Piastischen Herzogslinie, Breslau 1883.

Handbuch der historischen Stätten. Schlesien, wyd. H. Weczerka, Stuttgart 2003.

Historia Ślaska. Tom I do roku 1763, część I do połowy XIV w., red. K. Maleczyński, Wrocław 1960. Jasiński K., Rodowód Piastów ślaskich, t. I-III, Wrocław 1973-1977.

Jurek T., Obce rycerstwo na Ślasku do połowy XIV wieku, Poznań 1998.

Kaemmerer M., Ortsnamenverzeichnis der Ortschaften jenseits von Ode rund Neiße, Leer 1988.

Kozaczewski T., Kościól klarysek, dwór księżnej Anny a dom kupców, „Zeszyty Naukowe Politechniki Wrocławskiej. Architektura" 36, 1960, z. 4.

Kulig H., Die Standesverhältnisse des Breslauer Klarenstiftes im Mittelalter, Breslau 1939.

Moraw P., Das Mittelalter (bis 1469), [w:] Deutsche Geschichte im Osten Europas. Schlesien, red. N. Conrads, Berlin 1994.

Mrozowicz W., Dolny Ślqsk w latach 1327-1526, [w:], Dolny Ślask. Monografia historyczna, red. W. Wrzesiński, Wrocław 2006.

Orzechowski K., Historia ustroju Ślaska 1202-1740, Wrocław 2005.

Pater J., Poczet biskupów wrocławskich, Wrocław 2000.

Peschel C.W., Die Geschichte der Stadt Goldberg, t. I, Jauer 1821.

Prawo 321, 2016

(C) for this edition by CNS 
Ptak M.J., Zjazd ksiażat ślaskich z 1329 roku, „Prawo” CCCXIX, Wrocław 2015.

Schieche E., Politische Geschichte von 1327-1526, [w:] Geschichte Schlesiens, Band I von der Urzeit bis zum Jahre 1526, red. H. Aubin, Breslau 1938.

Schrage E.G., Górne Łużyce do roku 1346, [w:] Dzieje Górnych Łużyc. Władza, społeczeństwo i kultura od średniowiecza do końca XX wieku, red. J. Bahlcke, Warszawa 2007.

Śreniowski S., Historia ustroju Ślaska, Katowice-Wrocław 1948.

Šołta J., Zarys dziejów Serbolużyczan, Wrocław 1984.

Wojciechowski Z., Ustrój polityczny Ślaska, [w:] Historia Ślaska od najdawniejszych czasów do roku 1400, t. I, red. S. Kutrzeba, Kraków 1933.

Żerelik R., Dzieje Ślaska do 1526 roku, [w:] M. Czapliński et al., Historia Ślaska, Wrocław 2002.

\title{
The Congress of Silesian dukes of 1329
}

\author{
Summary
}

The study examines documents which originated in connection with a visit by the King of Bohemia and Poland, John of Luxembourg, to Wrocław in April and May 1329. So far scholars have pointed primarily to the reduction to vassalage of successive Silesian dukes from the Wroclaw line (Bolesław III of Legnica and Brzeg) and Głogów line (Henry of Żagań, Conrad of Oleśnica and John of Ścinawa). They have stressed the pressure exerted by the Bohemian king, which the various dukes were unable to withstand. The author has attempted to take a closer look at the contents of the extant documents, particularly vassalage documents. They show that the King of Bohemia convened a congress of dukes to Wrocław, during which matters of vassalage were negotiated not only for individuals but also for the various lines. The negotiations featured a two-person ducal deputation acting as a court of arbitration. The documents list the dukes' rights and freedoms with regard to the territories they governed and people settled there as well as the rights of the Bohemian king as the feudal lord. They also regulated the question of mutual relations between the dukes in property and other matters. Consequently, they should be viewed as the first written legislative acts fundamental and constitutional in nature, both in the various duchies and in their association referred to as the Duchy of Upper and Lower Silesia.

Keywords: Kingdom of Poland, Kingdom of Bohemia, Upper and Lower Silesia, dukes and ducal law, congresses of dukes, Silesian fiefdoms

\section{Zusammenkünfte der schlesischen Herzöge aus dem Jahre 1329}

\section{Zusammenfassung}

Zum Gegenstand der Bearbeitung wurden Dokumente, die im Zusammenhang mit dem Aufenthalt des Königs von Böhmen und Polen, des Johann von Luxemburg im April und Mai 1329 in Breslau entstanden sind. In der bisherigen Literatur wird vor allem auf die Vasalisierung weiterer schlesischer Herzöge der Breslauer (Boleslaus 3. von Liegnitz und Brieg) und Glogauer (Heinrich v. Sagan, Konrad v. Oels und Jan v. Scinawa) Linie hingewiesen. Hervorgehoben wurde dabei der durch den böhmischen König ausgeübte Druck, dem die einzelnen Herzöge sich nicht widersetzen konnten. Der Verfasser sah in die erhaltenen Dokumente ein und schenkte seine besondere Aufmerksamkeit den Lehensdokumenten. Aus diesen ergibt sich, dass der böhmische König die Zusammenkunft der Herzöge in Breslau einberufen hat, wo man die Angelegenheiten der Lehensverhältnisse 
nicht nur individuell, sondern auch gruppenweise verhandelte, im Rahmen einzelner Linien unter Beteiligung einer Zweipersonendeputation des Herzogs, die die Funktion eines Schiedsgerichtes erfüllte. In den Lehensdokumenten wurden die bisherigen Rechte und Freiheiten der Herzöge in Bezug auf die ihnen unterliegenden Gebiete und die dort ansässige Bevölkerung sowie die Rechte des böhmischen Königs als den Senior genannt. Sie regelten auch die gegenseitigen vermögensrechtlichen und sonstigen Verhältnisse zwischen den Herzögen. Folglich sind diese Dokumente als erste Rechtsakten eines fundamentalen und verfassungsrechtlichen Charakters anzusehen und das sowohl in den einzelnen Herzogtümern, als auch in ihrer Verbindung, für die der Name Herzogtum Ober- und Niederschlesien gängig ist.

Schlüsselworte: Regnum Poloniae, das Königreich Böhmen, Oberschlesien und Niederschlesien, Herzöge und Ius Ducale, Zusammenkünfte der Herzöge, schlesische Lehen 